\title{
DESIERTO Y PREDICCIÓN MATERIAL EN LA OCASIÓN DE JUAN JOSÉ SAER
}

\author{
Carolina Maranguello \\ Universidad Nacional de La Plata / CONICET \\ La Plata, Argentina \\ caromaranguello@yahoo.com.ar
}

\begin{abstract}
RESUMEN / ABSTRACT
La ocasión (1987), novela cuya intriga se ubica en las últimas décadas del siglo XIX, indaga el progresivo desencantamiento de la llanura santafesina en vías de modernización a partir de las sucesivas fallas de lo espiritual en sus distintas versiones - magia, misterio y adivinacióny del desvío de ciertas coordenadas románticas y sublimes del paisaje. Para ello, la escritura sobrevuela y yuxtapone, entre muchas otras, la ficción geológica de Darwin, las preocupaciones teosóficas y nacionalistas de Las fuerzas extrañas de Lugones, los relatos expedicionarios de Prado y la famosa pintura de Blanes sobre la fiebre amarilla. Ante el avance de la fuerza ciega del progreso capitalista, se intentará observar cómo mutan y se yuxtaponen anacrónicamente algunas de estas heterogéneas ficciones del desierto, y en particular, cómo la "magia" todavía resiste en la precariedad de los cuerpos.
\end{abstract}

Palabras clave: Juan José Saer, La ocasión, paisaje nacional, desierto, imagen.

\section{DESERT AND MATERIAL PREDICTION ON THE OCCASION OF JUAN JOSÉ SAER}

The occasion (1987), a novel whose intrigue is located in the last decades of the 19th century, investigates the progressive disenchantment of the Santa Fe plain in the process of modernization based on the successive failures of the spiritual in its different versions-magic, mystery and fortune telling-and the deviation of certain romantic and sublime coordinates of the landscape. For this, the writing flies over and juxtaposes, among many others, Darwin's geological fiction, the theosophical and nationalist concerns of Lugones 'strange forces, Prado's expeditionary tales and Blanes'famous painting of yellow fever. Before the advance of the blind force of capitalist progress, we will try to observe how some of these heterogeneous desert fictions mutate and juxtapose, and in particular, how "magic" still resists in the precariousness of bodies. 
KEYWORDS: Juan José Saer, The occasion, national landscape, desert, image.

Recepción: 21/11/2019

Aprobación: 24/02/2020

Ni telepatía, ni sortilegio ni mistificación: La ocasión expone al mundo como ruina desencantada. Contemporánea de la presidencia de Sarmiento (18681874), la acción de la novela culmina con la propagación de la peste amarilla en 1871. Algunas décadas antes, entre la magia blanca de la historia y la magia negra de la brujería, la escritura sarmientina, como embrujo y ritual, evocaba el cadáver salvaje de Facundo para conjurar y dominar sus fuerzas de curación y de terror en la letra ${ }^{1}$, e inscribía y fundaba en esa voz, el desierto. La ocasión indaga precisamente ese espacio a partir de su progresiva desacralización y desencantamiento, allí donde las distintas ocasiones del espíritu -profecías, telepatía, adivinación y religión- fracasan ante la fuerza ciega del avance capitalista $^{2}$. La novela retoma el viaje de la inmigración a través de la mirada descentrada del más extranjero de los viajeros, el misterioso Bianco, y se expide sobre un momento particularmente delicado de la historia argentina: aquel en el cual comienzan a definirse las líneas de la paideia nacional y el paisaje sufre las mutaciones que le impone la razón pragmática del progreso, que transforma la tierra sin límites en campos alambrados y determina nuevas formas de producción agrícola e importadora ${ }^{3}$.

1 Por su apelación constante a fuerzas y poderes ajenos, la letra de Sarmiento tiene "el aspecto temeroso de un embrujo" (79), señala Jens Anderman en Mapas de poder, quien analiza su escritura como "travesía" y cruce entre distintos planos topográficos, capaz de convocar y reordenar la magia de las "regiones altas" de la razón y de la biblioteca europea, pero también la magia negra de la barbarie, para ensancharse a través de la asimilación y el sometimiento ritual del Otro.

2 La novela yuxtapone diversas ocurrencias de lo enigmático, aunque por supuesto, no habría que soslayar, como advierte Quereilhac en Cuando la ciencia despertaba fantasías, las diferencias que subyacen entre ellas. Las indagaciones teosóficas, magnetológicas y espiritistas del último tercio del siglo XIX buscaron acercar sus descubrimientos al campo científico, y se distanciaron de las corrientes más irracionalistas de la mística, la religiosidad y de ciertas expresiones del decadentismo artístico.

3 En sucesivas ficciones, entre las que se destacan "El viajero" (La mayor), La ocasión, Las nubes y El río sin orillas, Saer retomará y discutirá la formación del imaginario de la pampa decimonónica. El desierto saereano se escribirá como un espacio intersticial fraguado entre las sucesivas formulaciones históricas, literarias, económicas y políticas que lo redefinieron a lo largo de la conformación del estado nacional y la certidumbre de su anomalía inconquistable. 
Se cuenta en La ocasión la historia de Bianco, un famoso mentalista extranjero que ha recorrido los principales salones europeos llevando adelante espectáculos de magia y ocultismo, convencido de la superioridad del espíritu por sobre la materia. En Francia es convocado por la Academia de Ciencias para probar sus dotes clarividentes y sufre el "escándalo" de su vida, humillado por aquellos que pretendían demostrar las supercherías de sus poderes telepáticos. Ultrajado, Bianco viajará a tierras americanas y llevará a muchísimos campesinos pobres a trabajar, a cambio de unas propiedades que ya le han sido asignadas por el gobierno argentino, convencido de que en la llanura, por su monotonía silenciosa, podrá recuperarse y escribir su refutación a los positivistas. Al llegar a Buenos Aires conocerá al doctor Garay López, hijo de una familia de la oligarquía de provincias cuyas tierras lindan con las de Bianco, al sur del Río Salado. Aunque indiferente a la materia, aprenderá rápidamente a dominarla y se convertirá en un exitoso colono propietario que proyectará cambios significativos en el campo. Se casará después con Gina, la hija de italianos humildes ya instalados allí. La vida de Bianco se dividirá entre sus retiradas al rancho construido en mitad del campo para reflexionar y escribir, y la casa que comparte con su esposa. Una tarde, al volver antes de lo planeado, descubrirá a su mujer y a su amigo en un clima de ambigua intimidad y placer. La perturbación y los celos lo dominarán desde ese momento y la escena vista lo obsesionará durante toda la obra, permaneciendo como un nudo irresuelto. La novela indaga y parodiza las tensiones entre la oligarquía criolla de la familia de los Garay López, el grupo de inmigrantes que es violentamente rechazado de sus tierras productivas y los sujetos desplazados locales, entre quienes será significativa la presencia del tape Waldo, un extraño niño, hijo de un gaucho desertor del Ejército Grande, que lanzará oscuras profecías en dísticos octosilábicos y medirá sus poderes espirituales con los de Bianco.

Terminada en apenas veinte días, La ocasión condensa sin embargo una escritura de larga duración. Efectivamente, en 1960, el año de publicación de En la zona (considerado el libro que da inicio a su literatura), Saer comienza

Saer escribirá, entonces, a contramano de algunas de las cristalizaciones más mentadas sobre la llanura (su legibilidad, su oportunidad para el desplazamiento y su propiedad expansiva). Como se verá, La ocasión es un eslabón fundamental y fundacional de estas indagaciones sobre el paisaje nacional que culminarán, con interesantes desplazamientos y experimentaciones, en Las nubes, allí donde el escritor dará un giro a su reescritura de la biblioteca viajera aligerando el tono pesimista y crítico anterior y privilegiando ciertas formas del humor y del delirio. 
a escribir el relato "La ocasión", que será retomado posteriormente en los setenta, hasta su versión definitiva -y relativamente distinta- en la novela homónima. Esta escritura, abierta y potencial, dibuja "otro comienzo" para la obra de Saer y permite comprender su interés por la fascinante biblioteca de viajeros y escritores nacionales del siglo XIX que había comenzado a leer durante aquellos años, reunidos en las colecciones El pasado argentino de Gregorio Weimberg y en la "Serie del medio siglo" de la Editorial Universitaria, que Saer conoce en Santa Fe y relee, instalado en Francia, desde la biblioteca de la Universidad de Rennes.

En este sentido, La ocasión no sería el despunte de un interés tardío sino la primera condensación novelada de indagaciones tempranas. La escritura sobrevuela y yuxtapone, entre muchas otras, la ficción geológica de Darwin, las preocupaciones teosóficas y nacionalistas de la época, los relatos expedicionarios de Ebelot y Prado, y el cuadro de Blanes sobre la fiebre amarilla. Saer escribe en el vértice de estas múltiples lecturas e imágenes sobre la formación del estado nacional a partir de una apropiación anacrónica, pesimista y experimental, deudora de Martínez Estrada, en relación con el carácter ilusorio del desierto 4 . En primer lugar, entre la potencia del statum romántico y el telos progresista (Andermann 39), la otredad fascinante de la barbarie que Sarmiento conjuraba, deviene aquí mera precariedad, signada en la vida animal de la familia del soldado desertor del Ejército Grande, en

\footnotetext{
En El río sin orillas, Saer reivindica en más de una oportunidad la figura de Martínez Estrada, con quien coincide en la indagación no esencialista de la historia nacional. Radiografía de la pampa, advierte Prieto, tiene un carácter fundacional e intenta construir una historia en un continente excluido de la historia a partir de una impronta metafísica y negativa que expone una visión desencantada y pesimista del pasado leído en relación al presente político del escritor. Perspectiva diacrónica y crítica que también Saer retomará en su tratado imaginario pero que funcionará también, condensada, en varios de sus textos de ficción, como ocurre efectivamente en La ocasión. El carácter ilusorio que Saer le atribuye al desierto será, en este sentido, una reescritura y un homenaje a Martínez Estrada, aspecto que tempranamente advirtió Gramuglio: "La novela elabora la imposibilidad de conocimiento y su lectura remite a la frase de Martínez Estrada: "Todo es espejismo en la llanura" (Gramuglio citado en Frassoni y Schettini 13). En Radiografía de la pampa leemos: "La amplitud del horizonte, que parece siempre el mismo cuando avanzamos, o el desplazamiento de toda la llanura acompañándonos, da la impresión de algo ilusorio en esta ruda realidad del campo. Es la pampa; es la tierra en que el hombre está sólo como un ser abstracto que hubiera de recomenzar la historia de la especie -o de concluirla. [...] La pampa es una ilusión; es la tierra de las aventuras desordenadas en la fantasía del hombre sin profundidad" (Martínez Estrada 12-13).
} 
la insignificancia de los caseríos y en el amortiguamiento a veces paródico de los géneros pictóricos, topográficos y literarios que formaron el imaginario de la época. En segundo lugar, frente a ese oxímoron de época de lo espiritualmaterial que la escritura indaga irónicamente en el fracaso estrepitoso del adivinador Bianco 5 , la narración desplaza el "don" de la magia como resto soberano en la carne anónima y precaria de los cuerpos y en la irrealización efímera del mundo como imagen.

\section{ROMPER EL HECHIZO}

"Deberíamos aceptar que primero está la magia y la magia está siempre en el comienzo y que no hay comienzo sin magia" (s/p), advierte César Aira en "El realismo", para señalar enseguida que los dones de la magia se gozan en la realidad más chata y que es necesario el corte radical del realismo para apreciar sus beneficios. Y el hechizo abre las aventuras de Bianco en el paisaje rioplatense, para romperse precisamente allí, en el umbral del viaje. Como se recordará, después de haber vivido en diferentes países y de haber convencido a cientos de campesinos pobres de Italia de instalarse en la llanura santafesina, Bianco arriba al puerto de Buenos Aires y lo primero que observa es el relieve costero: "La tierra sin relieves a ras del agua, sin una sola roca, penetrando en el gran río marrón que prolongaba el mar, la

$5 \quad$ En Cuando la ciencia despertaba fantasías, Soledad Quereilhac advierte una particular y productiva amalgama entre ciencia, espiritismo, prensa y literatura en la época de entresiglos, uno de cuyos productos fueron las fantasías científicas de varios escritores -Holmberg, Lugones, Quiroga y Chiappori-, preocupados en explorar un perturbador oxímoron de época, el de lo espiritual-material, que suponía que la investigación y la experimentación científicas permitirían comprender y develar muchos de los misterios del espíritu. En este sentido, cabría entender al personaje de Bianco en relación con los derroteros que transitó el movimiento espiritista desde sus comienzos, cuyos primeros cultores y médiums se sometieron muy tempranamente a las colaboraciones y refutaciones de las sociedades científicas, que sin embargo, se mostraban interesadas en sus elucubraciones. Como explica Quereilhac, "a medida que el movimiento teosófico se expandía, comenzaron a hacerse oír, también, las críticas de sus detractores" (128), como el informe escrito por la Society for Psychical Research que presentó como una de las mayores impostoras de la historia a la reconocida ocultista rusa Madame Blavatsky. 
costa desierta, el caserío insignificante" (Saer, La ocasión 27) ${ }^{6}$. Sin embargo, a pesar de la pobreza del paisaje, los inmigrantes se vuelcan arracimados y contemplan "como hechizados el borde de lo desconocido" (27) hasta que, en un determinado momento, Bianco "desvió la mirada del desierto estimulante que lo esperaba $[\ldots]$ y la fijó en el anular hinchado y rojo, deformado por un gran reborde de pus alrededor de la uña [...] el punto en el que su cuerpo concentraba los últimos vestigios de las humillaciones pasadas, la expulsión final de esos sedimentos de materia corrupta y engañosa" (Saer, La ocasión 28). Ese desvío de la mirada, desde la visión panorámica de la ciudad al absceso de pus, rompe el hechizo que subyuga a los inmigrantes a partir del detalle sintomático de la corrupción corporal. La ocasión empieza con ese corte radical y será, parafraseando a Aira, el relato de la extensión de un tiempo sin el don, o mejor, el de su relevo por el dinero, deseo moderno que empieza a ocupar el lugar de la magia ${ }^{7}$.

\section{DESAPARICIONES EN UNA MANCHA DE TINTA}

Entre el cálculo racional y la aparición fantasmagórica, una tropilla salvaje interrumpe las cavilaciones de Bianco en plena llanura. El desierto saeriano - como descalabro temporal y anacrónico- captura el devenir irreal del

\footnotetext{
Las aspiraciones económicas y civilizatorias del viaje -el interés del gobierno argentino de poblar las tierras al noroeste del país, los títulos de propiedad que carga Bianco sobre veinte leguas cuadradas de buenos campos y la promesa de trabajo y prosperidad hecha a los inmigrantes - se corresponden con esa vista urbana hecha desde el río, útil para los navegantes a la hora de identificar los puertos, que resultaba, sin embargo, un tanto desalentadora para quienes arribaban al puerto de Buenos Aires, en el que no eran distinguibles los accidentes geográficos tan característicos de otras zonas portuarias. Sobre el modelo topográfico "Vista desde el río" como dispositivo de dominio territorial, cfr. Ver, conocer, dominar. Imágenes de Sudamérica a fines del siglo XVIII de Marta Penhos.

En "El realismo", Aira reflexiona sobre el realismo a través de un análisis sorprendente de la historia de Aladino y advierte que, a diferencia de los deseos que Aladino le pide al genio (Aladino solo pide comida, y el genio satisface en abundancia su pedido, por eso su aprovechamiento se extiende al máximo en la historia, porque el joven vende la lujosa vajilla en la que fue servida la cena para comprar a su vez más alimentos para él y su madre, estirando de este modo el "don" a la manera del realismo), en la modernidad y con el triunfo del capitalismo, pediríamos "dinero": "porque la Historia ya ha hecho entrar al dinero en el terreno de la magia" (248), modalidad que abunda fundamentalmente en las novelas de Balzac, cuya "rama de magia era la manipulación financiera" (249).
} 
mundo ${ }^{8}$, allí donde los sujetos, los animales y los fenómenos atmosféricos abandonan su condición de real para centellear como imágenes y visiones ${ }^{9}$. La ocasión separa aquello que la iconografía y la literatura habían producido como un todo: el cuerpo del animal por antonomasia, el caballo, quedará ahora, por una operación de la imaginación saeriana, despojado de algunos de sus atributos, y sustraído de la lógica material que contabiliza cuerpos según la emergente racionalidad capitalista. Presencia continua y turbadora en varias de sus ficciones, los caballos reaparecen en La ocasión como tropilla salvaje que irrumpe en la llanura, y adquiere aquí, junto al paisaje, una consistencia plástica para ser, antes que materia efectiva del mundo, un borrón en la línea del horizonte:

El borroneo leve, móvil, que alteraba la línea en la que cielo y tierra gris se juntan, se ha transformado en una mancha nerviosa, alargada, que empieza a cobrar relieve sobre la línea horizontal, y poco a poco, $[\ldots]$ se desagrega y se transforma en una infinidad de puntos, y después de manchas oscuras que se sacuden y que van agrandándose, progresivas, y levantando un rumor [...]. La enorme tropa de caballos oscuros que se acerca a toda velocidad alborotando el desierto un poco adormecido $[\ldots]$ masa sombría y palpitante, de una multitud unificada por todos sus miembros y al mismo tiempo dispersa en cada uno de ellos. [...] Vigorosos, disciplinados y salvajes, parecen la pasta arcaica del ser desplazándose como un viento cósmico, dividida en un número indefinido de individuos idénticos [que cuando se alejan por el lado opuesto del horizonte] revela[n] la naturaleza insidiosa

8 En El río sin orillas, Saer precisará los efectos distorsivos de la llanura, que perturba las percepciones en dos sentidos: por un lado, en tanto espacio vacío que facilita la proliferación de lo idéntico y sigue una tendencia serial y repetitiva; y por el otro, volviendo abstracto aquello que lo atraviesa: "al cabo de cierto lapso la percepción ya no ve un caballo, tal como lo conocía en su campo visual, sino una masa oscura y palpitante, un ente problemático [...] que adquiere la nitidez enigmática de una visión" (Saer, río sin orillas 120).

En El espacio literario, Blanchot señala que "vivir un acontecimiento en imagen no es desprenderse de ese acontecimiento, [sino] dejarse tomar, pasar de la región de lo real, en la que nos mantenemos a distancia de las cosas para disponer mejor de ellas, a esa otra región donde la distancia nos retiene" (250). Y en este sentido, la experiencia que Bianco tiene al presenciar la manada de caballos salvajes es una experiencia exiliar: "lo que ocurre se apodera de nosotros como lo haría la imagen, es decir, nos despoja de ella y de nosotros, nos mantiene en el afuera, hace de ese "afuera" una presencia donde 'Yo' no se reconoce" (251). 
de su aparición fugaz y problemática, de materia rugosa o de visión. (Saer, La ocasión 28-32).

Como en "El intérprete" (La mayor) lo que viene desde el horizonte irrumpe primero como presencia plástica y luego se corporiza, se vuelve materia rugosa, piel, músculos y nervios, para recobrar después su presencia de mancha; no se trata en este caso de un malón indio ni de una avanzada del ejército, sino de una tropilla salvaje que irrumpe el aislamiento de Bianco, dejándole una doble preocupación, una contemporánea de sus cavilaciones, ¿cómo contabilizar y domesticar esos cuerpos dispersos?; una anacrónica, de la que participa el narrador, ¿cuán real es esa aparición?

Esta escena recupera, según puede constatarse en el dossier genético de La ocasión ${ }^{10}$, algunos fragmentos de La guerra al malón (1907) de Manuel Prado $^{11}$, en particular, el episodio sobre el robo de una tropilla reunida y cuidada especialmente por el coronel Villegas:

Formó un grupo de seiscientos caballos blancos, tordillos o bayos claros, destinados a servir de reserva o para el combate. Y aquella masa que de lejos parecía una bandada misteriosa de fantasmas, llegó a obtener renombre en la frontera. Los blancos de Villegas infundían terror en el aduar del salvaje; y no hubo malón que se atreviese a desafiar la rapidez y el aguante de aquellos fletes insuperables. Cuando el " $3^{\circ}$ de fierro" se enhorquetaba en su reserva parecía una tropa de titanes volando en alas del huracán (Prado 84-5).

Los "blancos" son el motín más preciado del desierto y los indios realizan un golpe maestro al llevárselos, poniendo en ridículo el honor de Villegas y la seguridad del campamento. Narrado en dos capítulos, el episodio concentra un gran interés dramático: Prado se detiene en la psicología de los soldados,

10 Mariana Di Ció señala que es posible encontrar entre el material prerredaccional una serie heterogénea de documentación que reúne textos y anotaciones dispares, desde fragmentos sobre el ápeiron y apuntes sobre la técnica del animismo hasta una detallada descripción de los síntomas y causas de la fiebre amarilla. Una parte de este dossier fue publicado en el primer volumen de los Papeles de trabajo bajo el título "Documentos y variantes de La ocasión (1961-1987)". Para la descripción del material preparatorio o prerredaccional y el material "a medio escribir", $c f r$. Di Cio, Mariana "A medio escribir".

11 La guerra al malón fue una memoria de guerra escrita por Manuel Prado a propósito de su participación en la Conquista del Desierto bajo el mando del Coronel Conrado Villegas, en la línea de fortines desde Trenque Lauquen hasta Choele Choel. 
pinta el perfil terrible del coronel y narra con dinamismo las escenas de guerra contra los indios en las tolderías. La escritura de Saer produce un trabajo de condensación y depuración: lo que resta del "robo de los blancos" es una pura imagen, una tropilla ciega que atraviesa el horizonte sin jinetes -ni indios ni soldados- que se disputen su dominio, sustraída incluso del afán utilitario y comercial de Bianco, que, fascinado ante la aparición, no puede calcular exactamente el número de caballos y corre detrás de ellos infructuosamente. Lo que resta del relato de Prado, como si Saer hubiera tamizado esa historia de frontera y trabajara con el sedimento concentrado de su narración, es la cualidad sublime de la tropilla, debida en gran parte a su carácter fantasmal y a su aparición en masa: "Y aquella masa que de lejos parecía una bandada misteriosa de fantasmas" (Prado 84) que Prado asocia a las ideas de huracán, tromba, tropa de titanes y soplo.

Esa variación plástica que detiene al paisaje entre lo nítido y lo fantasmal, se reitera un poco más tarde, en la escena en la que Bianco, después de haber mirado extasiado la tropilla, decide regresar antes de lo planeado a la ciudad:

El hombre y los caballos, encastrados en la llovizna, bien nítidos a causa de los destellos húmedos y grises, tienen sin embargo algo de fantasmáticos en el campo liso y vacío y tan idéntico a sí mismo en todas sus partes, que a pesar del trote rápido, ellos parecen estar realizando una parodia de cabalgata en el centro exacto del mismo espacio circular [...] hasta dar la impresión de que los cascos chapalean, en su pantomima monótona de cabalgata, en un charco de tinta (Saer, La ocasión 32- 33).

El escritor mantiene y exacerba las cualidades abstractas de la llanura - monotonía, vacío y uniformidad- pero tuerce su correlato épico: si en Ebelot, en Sarmiento y en Darwin, la extensión desmesurada era sinónimo de libertad y expansión, aquí es el movimiento el que se vuelve imposible, pantomima y simulacro, hasta que el mismo paisaje, sensible a sus elementos, termina empastándose en un charco de tinta.

\section{BAJO LA PIEL DEL MUNDO}

La lengua de La ocasión socava la candorosa convicción de Bianco sobre la superioridad del espíritu a partir de la potenciación material de su prosa y de la continua remisión a las superficies en, sobre y debajo de las cuales se 
asienta, discreto, para ausentarse, lo real. Se trata, para seguir una ocurrencia de Didi-Huberman sobre el arte escultórico de Giussepe Penone, de la posibilidad de "tocar el pensamiento" 12 :

[...] es verdad que, desde hace unos meses, sus pensamientos son semejantes a las hojas de los árboles, manchados de una especie de herrumbre, de un orín negruzco que destiñe sobre ellos o del que parecen venir impregnados, igual que un pedazo de metal enterrado durante mucho tiempo en el fondo del pantano, donde sustancias ignoradas y orgánicas han comenzado su disolución (La ocasión 180).

La voz narrativa toca el pensamiento de Bianco y el paisaje putrefacto lo conduce, inevitablemente, al exterior: "de modo que el aire enrarecido y pringoso que sale de sus pulmones, la bruma del horizonte [...] pueden ser un fluido único, una corriente homogénea de la que lo interno y lo externo no son más que las dos puntas inciertas y fluctuantes" (180). Por eso, y a pesar del desagrado que le produce, Bianco se dedicará a explorar la expansión material que lo rodea, y sufrirá las mutaciones necesarias del explorador y del colono propietario. Efectivamente, antes de ir a presentarse ante sus vecinos, los Garay López, pasa seis meses viviendo en la intemperie durante los cuales aprende el idioma y despliega una mirada infinitesimal sobre el paisaje. Sin embargo, "metido bajo la piel de la llanura [y habiendo] cavado en ella sus propias galerías como un topo" (87), no busca asimilarse sino diferenciarse mejor de aquellos que lo rodean ${ }^{13}$.

12 En Ser cráneo. Lugar, contacto, pensamiento, escultura, Didi-Huberman advierte que el trabajo escultórico del artista italiano Giuseppe Penone empuja hasta sus límites táctiles y más paradojales las imágenes de la profundidad y de la interioridad del pensamiento a partir de la extroversión material de algo que suele permanecer en la oscuridad como "ceguera táctil": las paredes internas de un cráneo.

13 Bianco no participa, sin embargo, de la "fantasía de inversión" que caracterizó a algunos viajeros, quienes, fascinados por los valores que aún conservaban indios y gauchos como último reducto resistente a la degradación de la burguesía, soñaban con participar de algún modo de esa vida dura pero heroica. Aquí Saer invierte las valoraciones y desestabiliza los atributos tradicionalmente asignados a la civilización y a la barbarie: si el gaucho o el indio estaban asociados a la fuerza ciega de la violencia -amén de los atributos positivos que les atribuyen algunos viajeros-, en Bianco lo que anida como fuerza ciega es el progreso económico, connatural a otros viajeros, como Ebelot, Bon Head o Darwin, pero exento en él de la piedad, el asombro y la nostalgia con la que ellos advierten la pérdida del pasado. 
Bianco rubrica con su cuerpo - sus caballos, el arma, la tinta y el papel- el límite de sus propiedades, adelantándose a la transformación que efectuará más tarde el alambrado de los campos, dispositivo, según sostiene Jens Anderman, que regula el pasaje entre topografía y tropografía, allí cuando el antiguo paisaje rural y sus habitantes desaparecen como sujetos históricos para convertirse en patrimonio literario y mítico de la nación ${ }^{14}$. La artificialidad pictoricista y explícitamente anacrónica de la novela y la desarticulación de los principales tópicos de la llanura indagan precisamente esa transformación; sin embargo, la contigüidad contagiosa entre cuerpo y territorio resiste y conserva, todavía, un resto enigmático, alojado no ya en las fuerzas del espíritu, como desearía Bianco, sino en la materia perecedera y engañosa: aquella que se dispersa en el flujo de los cuerpos innumerables de los caballos, pero también en la ilusoria proximidad de la carne de su esposa.

Gina es, en más de un sentido, el más allá de un cuerpo: flujo discreto y enigmático de una fuerza que se sustrae del dominio y de la propiedad; ensanchamiento vertiginoso de la piel, reproducción cuyo origen se desconoce. Su cuerpo es contiguo a la densidad opaca de la llanura, hecho de la misma pasta, y su rostro un territorio inextricable que a Bianco le gustaría reconocer a pesar de que nada se deslice en la superficie: "una simplicidad, tan diáfana y natural, podría ser la prueba, no de la inocencia que sugiere, sino de una desviación más grande" (Saer, La ocasión 101) ${ }^{15}$. Y una vez más, esa desviación estará concentrada en un detalle: Bianco recuerda que una vez, antes de casarse con Gina, la sorprendió mirando impasible una escena en la que un

14 En Historia del alambrado en la Argentina, Noel Sbarra explica cómo se incorporó el alambrado en los campos argentinos y argumenta que fue un factor fundamental en el desarrollo de una época nueva de la economía rural. El cercado modificó el paisaje y las faenas rurales que habían anotado con curiosidad los viajeros (se terminaron las rondas nocturnas para impedir la dispersión del ganado así como las boleadas de avestruces, venados y gamas): "La pampa fue domesticada: la llanura ilímite quedó encerrada en la jaula brilladora de los alambrados. Ya no es la pampa de Mac Cann, que la discurrió a su antojo; ni la de Darwin, al que impresionó hondamente su 'silencio de muerte', ni la de los increíbles baqueanos" (Sbarra 104).

15 Por supuesto, el retrato de Gina -y el triángulo amoroso que forman con Garay López y Bianco- está enmarcado, como señala Sarlo en "Mujer, pena y misterio", en ciertos protocolos de la novela de intriga amorosa que Saer reescribe de manera irónica. En El espesor del presente, Abbate advertirá además la importancia de los celos en la intriga, que Saer retoma, en clave cómica, de La prisionera y Albertina desaparecida, los tomos V y VI de En busca del tiempo perdido de Proust. 
caballo intentaba penetrar a un yegua, y solo pudo distinguir cómo sus uñas intentaban arañar y arrancar un pedazo de corteza "como si toda la emoción que Bianco esperaba encontrar en la cara, ya hubiese descendido a lo largo de su cuerpo y estuviese evacuándose por las uñas ovales y filosas" (113).

En Ante la imagen, Didi-Huberman reflexiona sobre la cuestión del detalle en la pintura y advierte que el conocimiento acercado de la tela esconde una aporía, puesto que aquello que respondería a la fineza de la observación y a la voluntad de deslindar la totalidad en sus mínimas unidades significantes e iconográficas, termina encontrándose con "la tiranía de la materia". Convendría pasar entonces de la superficie pulida del cuadro al espesor de la pintura, para encontrar en él no sólo detalles, sino trozos, un término que toma prestado de Proust, más cercano a la "duración temblorosa en lo visible" y al destello ${ }^{16}$. A diferencia del detalle como circunscripción perfectamente divisible del espacio figurativo y clave del espacio mimético, el trozo es una zona de intensidad coloreada, una intrusión que no puede nombrarse y que una vez descubierta permanece como algo problemático, provocando el derrumbamiento de la ilusión representativa e imponiéndose como soberanía de presentación de la materia pictórica. La ocasión se "acerca" a fragmentos reducidos de los cuerpos, no como detalles sino como trozos matéricos, y es allí cuando la delicada mano de Gina o el absceso de pus en el dedo de Bianco se vuelven síntomas y alojan, transitoriamente, fulguraciones de lo enigmático.

Del trozo a la expansión de lo gigante, el cuerpo de Gina se sustrae a las deliberaciones de Bianco y el paroxismo de esa materia se desencadena en una de las imágenes más pregnantes del texto. Cuando Bianco se arrodilla para ayudarla a bañarse:

Gina le parece enorme, casi infinita, prolongándose en círculos de carne que forman una vasta pirámide cuya cúspide, afinándose, parece ir a perderse en la penumbra del techo $[\ldots]$ durante unos segundos le parece percibir, del otro lado de la piel, de la protuberancia dura del ombligo [...] el magma de materia en acción, agitándose en combinaciones y en transformaciones sin límite, los charcos abigarrados

16 Si bien en La ocasión no se describen propiamente "pinturas", se retoma aquí esta reflexión porque permite pensar esa condición paradojal de la mirada que rige la novela, que a la vez que intenta "acercarse", se ve constantemente repelida por un exceso de materia que "desborda" y que se impone con la fuerza de una imagen. 
de sustancia entrechocándose y entremezclándose, sin otra finalidad que esa fabricación constante de humores, de tejidos, de concreciones repetitivas, pasajeras, monótonas, inhumanas (Saer, La ocasión 189).

La mirada de Bianco intenta pasar de la superficie -la piel tensa del vientre, la mirada impasible- hacia lo que se desata en su interior, porque sabe que, si pudiera dominarla, sería toda la materia la dominada. Sin embargo, como señala Susan Stewart, al revés de la miniatura, que representa lo íntimo y lo doméstico, lo gigante se abre hacia lo infinito, y guarda una relación fundamental con el paisaje y la naturaleza; y como fundamento del origen de la historia natural y de la historia política, representa siempre un exceso inaprensible.

\section{OTRO EPISODIO DE FIEBRE AMARILLA EN LA CIUDAD}

La lengua de La ocasión conjura y morigera el misterio que, reiteradamente, obsesiona a Bianco. El núcleo sentimental de la novela, la presencia creciente de los celos y la imagen perturbadora sobre la que la narración insiste agudizando su propio voyeurismo encuentra un desenlace inesperado que una vez más se aplica con obstinación sobre la piel, pura superficie material que el personaje desdeña. Como se recordará, el amigo y joven doctor Antonio Garay López, sobrio y elegante, con inclinaciones literarias y filosóficas, heredero de la élite criolla de provincias y descendiente melancólico del fundador Juan de Garay, cobra para Bianco dimensiones inesperadas cuando constata con perturbación el parecido físico que guarda con Gina:

parecían hechos de la misma sustancia, la misma pasta elástica, juvenil y nerviosa que había sido amasada de una sola vez y después repartida en dos mitades iguales para darles forma y soltarlos al mundo, llevando siempre la marca del origen común, e incluso la diferencia de sexo parecía borrarse (Saer, La ocasión 134-5).

La versión paranoica del origen de Bianco y Gina, como si fueran de la misma pasta -o formaran parte del mismo soplo que anima a los caballos y a la llanura- exacerba su propia extranjería y ha sido analizada como una semejanza siniestra que trasciende incluso voluntad y deseo y se constituye 
como la exteriorización de la materia que Bianco no puede someter ${ }^{17}$. Sin embargo, ese retrato ligeramente feminizado de Antonio Garay López (rostro excesivamente pálido y miembros delicados) sufre una fuerte transformación cuando éste regresa a la ciudad. Lo que alcanza a ver Bianco cuando vuelve a su casa después de haber recibido el extraño dístico profético de Waldo, es la versión grotesca y degradada de su caro dottore, desaliñado, con la cara hinchada y la piel de un rosa vivo encendido. Como se señaló antes, entre el material prerredaccional de La ocasión se encontraron abundantes anotaciones sobre las causas y sintomatología de la fiebre amarilla. La voz narradora abandona aquí la hipótesis filosófica del apeiron para moderar una descripción naturalista que, con ojo clínico, sigue metódicamente los síntomas de la enfermedad y describe el aliento fétido, la coloración roja sobre el rostro, y más tarde el violáceo amarillento y los puntos rojos que van cubriendo la piel. Sin embargo, más allá de esa documentación clínica que Saer efectivamente acopió entre sus cuadernos, la brusca aparición de Garay López en la ciudad evoca otros sentidos condensados en el imaginario de la época, no solo en relación al discurso higienista sino también al carácter dramático y épico de aquellos comprometidos en la cruzada contra la fiebre ${ }^{18}$.

En 1871 Juan Manuel Blanes pintó Un episodio de fiebre amarilla en Buenos Aires, uno de los cuadros más famosos de la historia del arte argentino ${ }^{19}$. El masivo impacto que produjo puede comprenderse cuando se observa que el cuadro condensa una serie de sentidos sociales que estaban en conflicto durante su ejecución. En primer lugar, la imagen fue tomada por Blanes de

$17 \quad C f r$."El tiempo cíclico de la barbarie", el tercer capítulo del libro de Rafael Arce, Juan José Saer: la felicidad de la novela.

18 En este sentido, Ralph Herne, la primera novela escrita por William H. Hudson (escritor y naturalista por quien Saer sentía admiración y a quien reescribió en más de una oportunidad) indaga precisamente la significación de la fiebre amarilla en el cruce del género sentimental. Como en La ocasión, se sugiere aquí un trío amoroso que termina de resolverse a la vez que se desanudan los estragos de la fiebre. Sin embargo, la escritura de Hudson no ahorra ningún matiz dramático y pondera la heroicidad de Ralph Herne, joven doctor inglés que ha ido a instalarse en Buenos Aires y se vuelve imprescindible en la lucha contra la peste.

19 Como afirma Laura Malosetti Costa, Blanes fue uno de los "primeros modernos" y formalizó algunas de las escenas fundantes de la historia nacional oficial. Desconocemos si Saer efectivamente tuvo en cuenta su pintura a la hora de recrear el episodio "local" de la peste, pero es imposible que lo desconociera porque el cuadro de Blanes formó parte del acervo visual y simbólico del público rioplatense desde su primera exposición en el foyer del Teatro Colón. 
un episodio efectivamente ocurrido y difundido en numerosos periódicos de la época: se había encontrado el cadáver de una joven mujer italiana, Ana Bristiani, de cuyo pecho un niño intentaba amamantarse en un cuarto de conventillo de la calle Balcarce. Los miembros de la Comisión Popular fueron representados en el cuadro por los retratos de Roque Pérez y Manuel Argerich, quienes iban en general acompañados de fuerzas policiales. Como se recordará, el lienzo muestra en primer plano las imágenes idealizadas de la mujer y del niño recostados en el piso del cuarto, mientras que en el margen izquierdo del cuadro se alcanza a ver el cadáver del padre tieso y acostado en su lecho. En el umbral de la puerta que divide lumínicamente la imagen entre el exterior iluminado por la luz diurna y el interior en sombra, se hallan tres personajes: el muchacho, seguramente otro inmigrante que ha dado aviso del lamentable hallazgo, y los ya mencionados Roque Pérez y Manuel Argerich, abogado masón el primero y médico el segundo, que miran respetuosamente la escena en un gesto de detención y recogimiento. Laura Malosetti Costa analiza las importantes variaciones entre el primer boceto de la obra y el lienzo terminado y encuentra allí, en las diferentes poses y gestos de los personajes, la conversión de "la crudeza y el morbo de la noticia en un objeto codiciable, apetecible, en un recuerdo 'civilizado' de la peste [...] un tránsito del pathos al ethos, de la barbarie a la civilización” (Malosetti Costa, Los primeros modernos 78).

El episodio saeriano de la peste parece invertir gran parte de la codificación visual y política del cuadro de Blanes. En primer lugar, Blanes buscaba exaltar los valores heroicos de la ciencia y el progreso y señalar, además, a los inmigrantes como los responsables por la difusión de la enfermedad ${ }^{20}$. Dos veces Bianco visita a Garay López durante su enfermedad para obligarlo a confesar sobre su relación con Gina, pero se encuentra con una declaración inesperada: fue él quien llevó la epidemia a la ciudad cuando, asustado, huyó del Hospital de Buenos Aires al darse cuenta de que al menos dos pacientes morían de fiebre amarilla. El esquema de la culpa se revierte: resultará entonces que un habitante legítimo de la civilización, hombre de ciencias y descendiente de conquistadores es quien dispersa la enfermedad, no por

20 En una entrevista sobre la reedición de Indios, ejército y frontera, David Viñas sostiene: "En la Argentina, en los años 1860 y 1870, la secuencia es: paraguayos, montoneros, indios. Liquidados, la búsqueda del otro distinto y peligroso termina en el inmigrante. Desaparecidas las tolderías convencionales, aparecen las 'tolderías rojas': los malones ya no vienen del Sur, sino de Barracas, o de La Boca...” (Prieto, Archivo de desapariciones s/p). 
causas heroicas sino porque teme el contagio. Pero además, es Bianco, al fin de cuentas, un inmigrante "italiano", el que lo visita en su lecho de muerte. Saer radicaliza la desacralización del episodio y se comporta como un verdadero pintor naturalista al describir detalladamente los estragos corporales de la enfermedad. A diferencia de la idealización que practica Blanes, embelleciendo a la mujer y borrando los síntomas de la fiebre -sorprende la blancura y el aspecto "saludable" del cadáver-y soslayando en la sombra el cuerpo del padre, la pintura de Saer focaliza en el cuerpo enfermo:

Enteramente desnudo, Garay López está tirado en la cama, sin almohada, inmóvil, los ojos bien abiertos clavados en el techo, y aparte del cabello y de la barba renegridos y de los pelos del pubis renegridos, toda la piel de su cuerpo es amarilla, azafranada, y, a causa del sudor, relumbra un poco contra las sábanas empapadas. No solo tiene el olor, sino también el color de la paja descompuesta (Saer, La ocasión 206).

En contraste también con la deferencia respetuosa de los representantes de la Comisión popular, que en el cuadro final de Blanes se han sacado el sombrero en señal de respeto y se detienen ante la imagen desgarradora, Bianco se adelanta y golpea suavemente con su bastón la mejilla tiesa de Garay López y lo instiga para que confiese. Por último, en el cuadro hay una oposición clara entre la oscuridad del interior del conventillo y la luz que viene del exterior, "una luz sanitaria", la llamará Daniel Santoro, porque viene precedida del dúo de doctores que le oponen, a la cruz que apenas se distingue sobre la cabeza del hombre muerto, la luz de la ciencia y el progreso, la luminaria del estado que llega para salvar, pero también para señalar, a los infectados. Los hombres, a contraluz, se recortan sobre el umbral y la atención lumínica se concentra en el pecho de la madre, convertida en un cuerpo deseable a pesar de la muerte. Saer borra las diferencias lumínicas entre el adentro y el afuera y, una vez más, fuerza una correspondencia entre el paisaje y aquellos sujetos hechos "de la misma pasta" que le da forma a la llanura:

Es igual que si los mismos cambios de color que contaminan la luz del sol, el horizonte y el follaje, estuviesen produciéndose en la piel humana, como si el mundo estuviese cambiando y las sustancias caprichosas que, combinándose entre ellas, $[\ldots]$ hubiesen decidido darle una apariencia extravagante, para variar el verde sempiterno de los árboles y el azul monótono del cielo (Saer, La ocasión 196). 


\section{MAGIA Y PRECARIEDAD}

En el mundo desencantado de La ocasión, la antigua fascinación de la barbarie ha cedido su lugar a la precariedad de los cuerpos y su deriva. Así se presenta la historia del gaucho desertor del Ejército Grande, cuya existencia vagabunda, "lo absurdo de su propia vida de desertor, de animal incomprensible y desnudo" (147), lo aleja y lo acerca de su familia: "un montón de larvas oscuras y exangües reptando en la llanura vacía, bajo un cielo vacío" (147), que vive amontonada en el rancho, "esa ruina inenarrable $[\ldots]$ con sus palos torcidos, $[. .$.$] esa especie de baldío cubierto de bosta y excremento de perros,$ de objetos rotos, inverosímiles e inútiles que había ido juntando igual que las vizcachas alrededor de su cueva" $(148)^{21}$. El animal no es aquí "el revés sistemático de lo humano, el confín de donde provenía el salvaje, el bárbaro y el indisciplinado" (Giorgi 11) sino una fuerza que desfigura lo humano como empastamiento ciego y anónimo, en contigüidad con la vida comunitaria y subterránea de las vizcachas y la indefinición desfigurante de las larvas. Una contigüidad que clausura las dicotomías clásicas de civilización y barbarie porque es precisamente de esa precariedad de vida de la que emerge el acto fundante de la cultura: la muerte del padre violento y la emergencia inédita del don profético del tape Waldo ${ }^{22}$.

Como se recordará, esta historia encuentra su inicio en las batallas del Ejército Grande, pero su desarrollo es contemporáneo de la historia principal. La narración desanuda los flujos que trazan los personajes sobre la llanura: las apariciones esporádicas que el gaucho desertor hace en su rancho para embarazar a su mujer o violar a sus hijas mayores y las peregrinaciones milagrosas del tape Waldo y La Violadita, después de haber sido liberados de su padre por la acción justiciera de sus hermanos mayores. Waldo, que al presenciar el homicidio de su padre había gemido durante meses hasta callar por completo, recupera la posibilidad de hablar pero solo lo hace para

21

En relación al vínculo que La ocasión establece con novelas como En la sangre, de corte naturalista y de cuño lombrosiano, en la que aparecen animalizaciones, $c f r$. Abbate "La ocasión", en El espesor del presente.

22 Otra zona de la divulgación científica, señala Quereilhac, también explorada en los medios de prensa de la época, era el caso de los llamados "sensitivos": los médiums, los niños prodigio y clarividentes o las mujeres que podían percibir la inminencia de la muerte. Muchos de estos "casos" fueron noticia en las revistas y materia de elucubración literaria. En este sentido, la extraña historia de Waldo podría haber sido la de uno de estos "sensitivos". 
lanzar oscuras profecías en dísticos octosilábicos. Cuando su fama empieza a crecer y ya han recorrido los caminos, pasan a la ciudad. Allí los visita Bianco para probar la autenticidad del fenómeno y advertir que finalmente Waldo no podía ser un mistificador, aunque fuera, igual que todos, extranjero de sus propias palabras: "ese don no le viene de las palabras [...] el rumor condescerá durante unos instantes a transvasarse imperfectamente en palabras que serán, respecto de él, sin excepción, inevitablemente extranjeras” (Saer, La ocasión 175-6). Los versos confusos del tape Waldo reviven las esperanzas de sentido de "los que miran perplejos transcurrir sin razón aparente los días y las noches [...] los que se mueren de hambre, de frío, de tristeza, en los baldíos borrosos de los arrabales" (219). La magia reaparece finalmente en la realidad más chata y precaria, regida por aquellos marginados de las guerras patrias: la hermana mayor de La Violadita, hija de un gaucho desertor y ex prostituta, y un sargento retirado de la Guerra del Paraguay. El mecanismo que activa el "don" y que perfecciona el dispositivo no es otro que el de una emergente empresa capitalista familiar que intercambia versos apenas audibles y difícilmente codificables por caramelos, billetes y regalos.

La historia de Waldo y su familia retoma, por último, una de las imágenes clave de la llanura, la ficción geológica del imaginario darwiniano:

Los llamaban de todas partes y ellos cruzaban el campo en todas direcciones [...] hasta las cercanías de Córdoba, en los caseríos precarios que iban formándose en la superficie chata de la tierra más antigua del mundo, cubierta por el sedimento de continentes y de especies desaparecidas y molidas por el tiempo y por la intemperie, ese espacio irreal y vacío que los conquistadores ponían especial cuidado en esquivar (Saer, La ocasión 163).

En diálogo con la hipótesis evolutiva de Darwin ${ }^{23}$, Saer imagina la llanura como el futuro que le espera al resto del mundo:

23 El Diario del viaje de un naturalista alrededor del mundo fue el resultado de la famosa expedición que Charles Darwin (1809-1882) realizó siendo todavía un joven naturalista a fines de 1831 en el HMS Beagle, al mando del capitán Robert Fitz Roy. Uno de los aspectos que interesa subrayar aquí, por su relación con la prosa saeriana, es que la "ficción geológica" y la "ficción evolutiva" desarrolladas por Darwin fueron posibles por su particular forma de percepción temporal. Al respecto, Fermín Rodríguez señala que el naturalista era capaz de detenerse en detalles y texturas en los que podía percibirse el paso lento e imperceptible del tiempo: "La historia natural produce una nueva máquina de hacer hablar la vida, de arrancarla de su fijeza por medio del lenguaje, según una ficción geológica atenta a las huellas escritas 
Eran como una persistencia irrisoria que, desafiando sin saberlo la molienda cósmica que había puesto la llanura pelada como ejemplo de lo que les esperaba a los otros continentes, a las cimas supuestamente majestuosas y a las nieves ilusoriamente eternas, a las especies ávidas y en pretendida evolución, cruzaban al paso los campos desolados $[\ldots][y]$ aun los indios [...] los dejaban seguir su camino (Saer, La ocasión 163).

Como ha sugerido Adolfo Prieto, Darwin sucumbe algunas veces a las “ensoñaciones cosmogónicas", esos momentos en los cuales, capturado por una evidencia misteriosa del presente, se retrotrae imaginariamente al comienzo de los tiempos. Así, la comparación entre los hallazgos fósiles de la costa entrerriana y los de Carmen de Patagones desemboca en "un juego especulativo que no tarda en convertirse en verdadera imaginación poética, y los huesos, y las conchillas y las arenas se abren a la fascinante y novedosa descripción de un Génesis con plataformas continentales que se desplazan, con tierras que surgen del fondo del mar, con especies animales que transmigran y cambian" (Prieto, Los viajeros ingleses 79). Seducido por el juego de las imágenes, estas ensoñaciones no caben en el lenguaje del naturalista y desbordan hacia lo poético ${ }^{24}$. También en Saer la ficción histórica se fuga hacia la espiral - poética y visual- de la imaginación geológica para amortiguar, sin embargo, su carácter sublime, porque ese paisaje chato y pelado, contingente ${ }^{25}$, es lo que les espera a las cumbres majestuosas y a las selvas espesas repletas de especies en pretendida evolución ${ }^{26}$.

sobre la superficie de las cosas, a sus roces, sus contactos, sus texturas, rugosidades y durezas" (82). Una temporalidad, como también ocurrirá en Saer, que excede la medida humana y deshumaniza el paisaje.

$24 \quad$ Fermín Rodríguez apunta este trasvasamiento: "El acto de imaginación del naturalista, que sostiene el despliegue del paisaje, vacila por una pasión que resquebraja la mesura estética: la experiencia de lo sublime, lo impensable tomando cuerpo en la llanura" (72-73).

25 En El río sin orillas, Saer desarticula la especificidad del paisaje rioplatense apelando a una historización de larga duración capaz de saltar de la captura del instante al tiempo de los orígenes geológicos y cósmicos del universo: "Los grandes ríos que forman el de la Plata, multiplicándose a medida que bajan del norte [...] no tienen nada de exótico y son el resultado de una serie de contingencias geológicas, geográficas y humanas en las que, por debajo del color local, el Logos común prosigue el soliloquio de su empastamiento con el mundo (Saer, río sin orillas 219-20).

26 Saer parece rescatar aquí la reflexión final de Darwin, cuando en su diario de viaje, después de haber reconocido la falta de grandeza de la llanura, se pregunta: “¿Por qué, pues, 


\section{ESPIRITUALISMO Y CAPITAL EN TIERRAS DE PROMISIÓN}

Ni el magnetismo de la barbarie, ni los dotes del vidente, La ocasión permite observar el ocaso de las fuerzas extrañas que a fines del siglo XIX todavía se entreveraban y convivían con el proyecto de modernización del campo, una intersección que puede verse en algunos relatos de Lugones en los que conviven el progreso rural y la experiencia espiritista y científica ${ }^{27}$, porque si bien es cierto, como señala Fermín Rodríguez, que Bianco cumple, como colono, el programa civilizatorio modernizador, lo hace tomado por una fuerza ciega de la que incluso él parece ser, por momentos, un agente involuntario. Como señala Quereilhac, en Lugones cabría encontrar "la proyección fantástica de un sueño espiritualista: el despliegue fabuloso de la intensidad del espíritu por sobre la debilidad de la materia" (209). En La ocasión, por el contrario, el imaginario espiritista de Bianco se paraliza ante la otra "fuerza ciega" que lo anima: la racionalidad pragmática del progreso "licúa", para tomar una metáfora de "El Psychon", las posibilidades adivinatorias de Bianco y vuelve a mostrar su estrepitoso fracaso. Pero además, La ocasión se desentiende de las formas de la paideia nacional que había comenzado a movilizar el libro de Lugones porque, como subraya Dalmaroni ${ }^{28}$, el escenario pedagógico que aquí se ponía en juego se debatía entre dos niveles de enseñanza, la destinada a aquellos poco capacitados para aprender lo incógnito ("La fuerza Omega", "El psychon") y la educación de "los muchos que deben ser educados en una koiné normalizada por el amo" (Dalmaroni, Una república de las letras 112)

estos áridos desiertos han echado tan profundas raíces en mi memoria? [...] Difícilmente puedo analizar estos sentimientos; pero en parte dimanan del libre campo dado a la imaginación. Las llanuras de Patagonia son sin límite; [...] llevan el sello de haber permanecido como están hoy durante larguísimas edades, y parece que no ha de haber límite en su duración futura. Si nos pusiésemos en el caso de los antiguos, que consideraban la tierra como una llanura rodeada de una zona infranqueable de aguas o de desiertos caldeados por un calor irresistible, ¿quién no miraría estos límites postreros de las exploraciones humanas con un sentimiento de profunda y vaga curiosidad?" (Darwin 411).

$27 \quad$ El paisaje agrícola de algunos relatos de Lugones puede alojar narraciones extraordinarias y permitir contactos con otras dimensiones espirituales. Cfr. por ejemplo, "Un fenómeno inexplicable".

28 En "El juicio del siglo: Leopoldo Lugones revisitado", Dalmaroni advierte que en Las fuerzas extrañas ya comienza a delinearse la paideia estatal imaginada por Lugones, que profundizará, convocado por Joaquín V. González, en El imperio jesuítico, Odas seculares y Didáctica. 
que no debe excederse en la "paciente integración pedagógica" si es que no se quiere poner en peligro el estado y la ciudad ("Yzur", "Los caballos de Abdera", "La lluvia de fuego"). La ocasión toca tangencial e irónicamente estos conflictos: Bianco fracasa en su comercio con las fuerzas extrañas y falla en su intento de transmitirle a Gina sus inquietudes telepáticas (con ironía la novela reitera las estampas casi infantiles y simplonas de las cartas que Bianco pretende, en vano, adivinar), sin embargo es quien puede, aún indiferente y ajeno a las preocupaciones del estado nacional, domesticar y conducir tanto las expectativas de la masa inmigratoria que lleva a los confines sudamericanos como las formas anticuadas de la oligarquía nativa representada en Juan, el hermano barbarizado de López Garay.

El último de los desplazamientos que ofrece la novela es el éxodo masivo de aquellos que huyen de la peste, entre ellos, Bianco y Gina a punto de dar a luz. La pareja se aleja hacia el campo y una vez más el paisaje se vuelve imagen cuando se desplazan lentamente en un carro tirado por bueyes: "se diría que $[. .$.$] alguien va tirando el paisaje entero hacia atrás, haciendo$ estremecerse a los bueyes y al carro a cada sacudida, igual que si estuviesen pegados a la alfombra beige que hace las veces de suelo" (Saer, La ocasión 210). La ironía final que le espera a Bianco es que será precisamente allí, en ese rancho filosófico minimalista, pensado para escribir su refutación a los positivistas, el lugar del pacto económico con Juan, el verdadero patrón del campo, que caerá rendido, nueva ironía, bajo el influjo material y venenoso del vientre en expansión, aquel cuya paternidad permanecerá desconocida.

\section{CONSIDERACIONES FINALES}

La ocasión captura las últimas luces del desierto en el umbral de su transformación definitiva y produce efectos de condensación y aceleración del tiempo, al abrir el paisaje nacional a su propio anacronismo y a la deriva crítica del origen. Saer desarticula la fundación histórico-política del Estado en términos de programa voluntario y épico de conquista para mostrar lo irrisorio de su implementación, fundada, entre otras cosas, en la deriva azarosa de un frustrado mentalista extranjero que, con indiferencia y algo de desprecio, cumple las expectativas del proyecto modernizador, aun cuando privilegiara en su fuero íntimo el espíritu por sobre la materia. Pero además, la novela atestigua el desencantamiento de las letras que fundaron la nación, desde la escritura embrujada de Sarmiento, fascinada ante la barbarie, a las 
prosas menores que intercambian Garay López y Bianco: cartas y contratos comerciales, y sobre todo, en relación a aquello que Bianco no logra escribir: la refutación a los positivistas que quizás le hubiera permitido recuperar sus dones adivinatorios y mágicos, cuando el rancho minimalista que le servía para pensar es ocupado por el lugar del pacto comercial. Ya sea mediante el arte predictivo del tape Waldo, las dotes visionarias de Bianco, o el presagio geológico darwiniano, La ocasión apunta a un futuro que se revela siempre como ininteligible y despojado de sus atributos románticos. Sin embargo lo que sí se sostiene y crece es la imagen de una pampa futura configurada por la mirada pragmática que proyecta alambrar los campos, fabricar ladrillos, fomentar la agricultura por sobre el modelo ganadero y exportar trigo para venderlo en los mercados europeos.

Ante los continuos fracasos de Bianco, incapaz de determinar si el hijo que espera Gina es suyo e incluso de adivinar el revés de los naipes, la narración reinscribe la pulsión material del ojo y de la mano, produciendo en la novela esa travesía que anunciaba el narrador de "Carta a la vidente", del ojo a la mano: la musa manual de La ocasión recorre con aterrado fervor las pieles, texturas y superficies del mundo, para encontrar que la fuerza enigmática del espíritu y las formas menores de la magia campean todavía en la precariedad anónima de algunos cuerpos en la llanura, y también en lo que el desierto hace con ellos al dejarlos en esa región intermedia y exiliar de las imágenes.

\section{BIBLIOGRAFÍA}

Abbate, Florencia. El espesor del presente. Tiempo e historia en las novelas de Juan José Saer. Villa María: Eduvim, 2014.

Aira, César. "El realismo". Sandra Contreras (ed.). Realismos: cuestiones críticas. Rosario: Universidad Nacional de Rosario, 2013. 239-256. Disponible en https:/www.academia. edu/33667486/Realismos_cuestiones_cr\%C3\%ADticas

Anderman, Jens. Mapas de poder. Una arqueología literaria del espacio argentino. Rosario: Beatriz Viterbo Editora, 2000.

Arce, Rafael. Juan José Saer: la felicidad de la novela. Santa Fe: Ediciones UNL, 2015.

Blanchot, Maurice. El espacio literario. Barcelona: Paidós, 2015.

Dalmaroni, Miguel. Una república de las letras: Lugones, Rojas, Payró: Escritores argentinos y Estado. Rosario: Beatriz Viterbo Editora, 2006.

"El juicio del siglo: Leopoldo Lugones revisitado". Castilla. Estudios de Literatura 1, 2010: 408-419. Disponible en https://revistas.uva.es/index.php/castilla/article/view/38 Darwin, Charles. Viaje de un naturalista por América del Sur. Buenos Aires: Terramar, 2013. 
Di Ció, Mariana. “Juan José Saer, a medio escribir”. Cuadernos LIRICO 6, 2011: 159-172.

Didi-Huberman, Georges. Ante la imagen. Pregunta formulada a los fines de una historia del arte. Murcia: Cendeac, 2010.

Ser cráneo. Lugar, contacto, pensamiento, escultura. Bogotá: Universidad Nacional de Colombia, 2008.

Frassoni Fernando y Adriana Schettini. "Las claves múltiples”. Página/12, jueves 8 de septiembre de 1988. 13.

Giorgi, Gabriel. Formas comunes. Animalidad, cultura, biopolítica. Ciudad Autónoma de Buenos Aires: Eterna Cadencia, 2014.

Lugones, Leopoldo. Las fuerzas extrañas. Buenos Aires: Agebe, 2012.

Malosetti Costa, Laura. Los primeros modernos: Arte y sociedad en Buenos Aires a fines del siglo XIX. Buenos Aires: Fondo de Cultura Económica, 2003.

"La cuestión del público en la gestación de un arte nacional. El caso de Juan Manuel Blanes". Las artes en el debate del quinto centenario: IV Jornadas de Teoría e Historia de las Artes. Centro Argentino de Investigadores de Arte. Buenos Aires: Talleres gráficos de la Facultad de Filosofía y Letras, 1992. 156-63. Disponible en http://www.caia.org.ar/ docs/24-Malosetti\%20Costa.pdf

Martínez Estrada, Ezequiel. Radiografía de la pampa. Buenos Aires: Losada, 2011.

Penhos, Marta. Ver, dominar, conocer. Imágenes de Sudamérica a fines del siglo XVIII. Buenos Aires: Siglo XXI, 2005.

Prado, Manuel. Guerra al malón. Buenos Aires: Editorial Universitaria de Buenos Aires, 1960.

Prieto, Adolfo. Los viajeros ingleses y la emergencia de la literatura argentina. Buenos Aires: Sudamericana, 1996.

Prieto, Martín. "Archivo de desapariciones" (entrevista con David Viñas). Clarín. Buenos Aires, 26 de abril de 2003. Disponible en http://edant.clarin.com/suplementos/ cultura/2003/04/26/u-00601.htm

Breve historia de la literatura argentina. Buenos Aires: Taurus, 2006.

Quereilhac, Soledad. Cuando la ciencia despertaba fantasías: prensa, literatura y ocultismo en la argentina de entresiglos. Buenos Aires: Siglo XXI, 2016.

Rodríguez, Fermín. Un desierto para la nación. La escritura del vacío. Buenos Aires: Eterna Cadencia, 2010.

Saer, Juan José. La ocasión. Buenos Aires: Seix Barral, 2010.

El río sin orillas: tratado imaginario. Buenos Aires: Seix Barral, 2003.

Papeles de trabajo II. Borradores inéditos. Buenos Aires: Seix Barral, 2013.

Sarlo, Beatriz. "Mujer, pena y misterio". Escritos sobre literatura argentina. Buenos Aires: Siglo Veintiuno, 2007. 286-288.

Sbarra, Noel H. Historia del alambrado en la Argentina. Buenos Aires: Eudeba, 1964.

Stewart, Susan. On longing: Narratives of the Miniature, the Gigantic, the Souvenir, the Collection. Durham; London: Duke University Press, 1993.

Viñas, David. Indios, ejército y frontera. Ciudad autónoma de Buenos Aires: Galerna; Buenos Aires: Santiago Arcos editor, 2013. 